\title{
In Vitro Ovicidal and Larvicidal Activities and Ultrastructure of Ascaridia galli in Native Chickens Treated Using Betel Nut (Areca catechu) Extract
}

\section{Wida W. Mubarokah ${ }^{1}$, Bambang Sudarmanto ${ }^{1}$, Wisnu Nurcahyo ${ }^{2}$, Joko Prastowo ${ }^{2}$, Kurniasih Kurniasih ${ }^{3}$, Priyo Sambodo ${ }^{4 *}$}

${ }^{1}$ Politeknik Pembangunan Pertanian Yogyakarta Magelang, JL. Magelang, Kopeng Km. 7 Kotak Pos 152 Tegal Rejo. Magelang, 56101, Indonesia, ${ }^{2}$ Department of Parasitology, Faculty of Veterinary Medicine, Universitas Gadjah Mada, Jl. Fauna No. 2, Caturtunggal, Kecamatan Depok, Karangmalang, Karang Gayam, Caturtunggal, Kec. Depok, Kabupaten Sleman, Daerah Istimerwa Yogyakarta, 55281, Indonesia; ${ }^{3}$ Department of Pathology, Faculty of Veterinary Medicine, Universitas Gadjah Mada, Jl. Fauna No. 2, Caturtunggal, Kecamatan Depok, Karangmalang, Karang Gayam, Caturtunggal, Kec. Depok, Kabupaten Sleman, Daerah Istimewa Yogyakarta, 55281, Indonesia; ${ }^{4}$ Department of Animal Science, Papua University, Jl. Gunung Salju, Amban, Manokwari, Papua Barat, 98314, Indonesia.

\begin{abstract}
Ascaridia galli (A. galli), a parasitic roundworm, is most frequently found in birds and can inflict economic loss. Treatment and prevention of infection by the worm are achieved through various methods, such as by using plants containing antiparasitic agents. The aim of this study was to investigate the ovicidal and larvicidal activities of and ultrastructural changes caused by Areca catechu crude aqueous extract (AAE) in eggs and larvae (L2) in vitro. The ovicidal and larvicidal activities were tested by soaking eggs, eggs containing embryos, and larvae (L2) for $48 \mathrm{~h}$ at $10 \%$, $12.5 \%, 15 \%, 17.5 \%, 20 \%, 22.5 \%$, and $25 \%$ AAE. The positive control was $5 \%$ pyrantel pamoate and the negative control was $0.62 \%$ saline water. Subsequently, the dead and the live eggs, the eggs containing embryos, and the L2 larvae were counted, and the eggs and L2 larvae were examined using scanning electron microscopy (SEM). The 12.5-25\% AAE had significantly different ovicidal and larvicidal activities $(p<0.05)$ compared to the control. The most intense ovicidal and larvicidal activities occurred at 25\% AAE, but they did not differ significantly from the ovicidal, larvicidal, and vermicidal activities of the positive control (pyrantel pamoate; $p>0.05$ ). The SEM results showed that there were shrinkages, ruptures, and general damages on the surfaces of the egg walls. Additionally, the anterior teguments of the L2 larvae shrank and the cuticles got ruptured at 25\% AAE. It can be concluded that AAE has ovicidal and larvicidal activities against $A$. galli and can thus be used as an anthelmintic.
\end{abstract}

Keywords | Betel nut, Ascaridia galli, Ovicidal, Larvicidal, Ultrastructure

Received | May 25, 2021; Accepted | August 10, 2021; Published | September 25, 2021

*Correspondence | Priyo Sambodo, Department of Animal Science, Papua University, Jl. Gunung Salju, Amban, Manokwari, Papua Barat, 98314 , Indonesia; Email: drh_priyo01@yahoo.com

Citation | Mubarokah WW, Sudarmanto B, Nurcahyo W, Prastowo J, Kurniasih K, Sambodo P (2021). In vitro ovicidal and larvicidal activities and ultrastructure of Ascaridia galli in native chickens treated using betel nut (Areca catecbu) extract. Adv. Anim. Vet. Sci. 9(11): 1838-1843.

DOI | http://dx.doi.org/10.17582/journal.aavs/2021/9.11.1838.1843

ISSN (Online) | 2307-8316; ISSN (Print) | 2309-3331

Copyright (C) 2021 Mubarokah et al. This is an open access article distributed under the Creative Commons Attribution License, which permits unrestricted use, distribution, and reproduction in any medium, provided the original work is properly cited.

\section{INTRODUCTION}

$A$ scaridia galli ( $A$. galli), a parasitic roundworm most frequently found in birds, can inflict economic loss by causing histopathology, such as intestinal epithelial degeneration and inflammatory cell infiltration in mucous, thus inhibiting proper nutrient absorption (Salam, 2015). The symptoms of heavy infection include retarded growth, emaciation, anorexia, anemia, diarrhea, dehydration, and decreases in body weight and egg production (Teixeira 
et al., 2012; Cervantes-Rivera et al., 2016; Yusuf et al., 2016). Synthetic anthelmintics are the main treatment for A. galli infection in native chickens, and $A$. galli infection is commonly treated using synthetic anthelmintics such as piperazine, ivermectin, and albendazole (Salam, 2015; Abbas et al., 2016). These medicines, however, are costly, cause poultry meat to be contaminated with the carcinogenic drug residue and promote resistance to drugs if used long term. Thus, many innovative alternatives to anthelmintics have been found, such as plants containing tannin, which has been reported to have the ability to reduce the incidence of worm infestation.

One of the innovations that have been brought about by the discovery of new anthelmintics is the use of new biological sources to support business success by improving livestock performance. Many biological sources have been used by breeders and researchers to help improve the performance of their livestock. For example, alternative sustainable internal parasite infestation control has been achieved using plants containing antiparasitic agents, and the traditional use of plants for anthelmintic therapy is now a common practice in developing countries (Lalchhandama et al., 2009). One of the plants used for their anthelmintic properties, betel nut, belongs to the Aereaceae family and contains active substances such as flavonoids, tannins, saponins, monoterpenes, sesquiterpenes, phenols, quinines, and alkaloids (arecoline and arecaidine) (Amudhan et al., 2012). The seeds are the parts of the betel plant that are widely studied (Prastowo et al., 2017; Balqis et al., 2017; Mubarokah et al., 2019), besides the roots (Baby and Raphael, 2014) and the stems (Adate et al., 2012). Betel nut is a plant that is widely available in Indonesia and has various benefits, such as being used as a construction material, a medicine, an economic commodity, and a craft material (Silalahi, 2020; Erwiyani et al., 2021). The goal of this study was to investigate the in vitro ovicidal and larvicidal activities of and ultrastructural changes caused by a crude aqueous extract of betel nut against $A$. galli.

\section{MATERIALS AND METHODS}

\section{Preparation of $A$. Catechu Crude aQueous extract} (AAE)

As in the study conducted by Daryatmo et al. (2010) to screen forages for anthelmintic activity, AAE was prepared by chopping up or slicing betel nut into small pieces. Different concentrations of AAE (10 g, $12.5 \mathrm{~g}, 15 \mathrm{~g}, 17.5$ $\mathrm{g}, 20 \mathrm{~g}, 22.5 \mathrm{~g}$, and $25 \mathrm{~g}$ ) were then prepared, and each was placed in a glass beaker with $100 \mathrm{~mL}$ water. The beakers were then placed in a $90^{\circ} \mathrm{C}$ oven and were kept there for 15 min. The remaining liquid in each beaker was then filtered to obtain various AAE concentrations.

\section{Testing OF OVICIDAL ACTIVITY}

Fifty female $A$. galli were obtained from the intestinal lumena of butchered free-range chickens obtained from local slaughterhouses in Yogyakarta, Indonesia. The live worms were immediately placed in beakers, and then a $0.62 \%$ saline water solution was added. All the female worms were collected, and each was cut along the darklight boundary of the posterior porous genitalis part. The uterus and eggs were removed by squeezing the worms' bodies, which were later discarded. As in the study by Coles et al. (1992), an egg suspension (0.3 mL; 1,000 eggs) was distributed into 27 wells of a microtiter plate with various AAE concentrations (10\%, 12.5\%, 15\%, 17.5\%, $20 \%, 22.5 \%$, and $25 \%$ ), along with the positive control (5\% pyrantel pamoate) and the negative control $(0.62 \%$ saline water). The eggs were then incubated at ambient temperature $\left(27^{\circ} \mathrm{C}\right)$, and after $48 \mathrm{~h}$, a drop of Lugol's solution was added to each well. The live eggs absorbed the red color in their walls while the dead eggs did not. All the live eggs in each well were counted three times, and the numbers were recorded.

\section{TESTING OF LARVICIDAL ACTIVITY}

The worm eggs were placed in a glass beaker containing $50 \mathrm{~mL} 0.5 \mathrm{NaOH}$. The eggs were embryonized using the modified Fairbairn method (Maclnnis and Marietta, 1970). The centrifuged eggs were placed in an Erlenmeyer flask containing $150 \mathrm{ml}$ distilled water. An oxygenator pump was inserted into the flask, the flask was plugged with cotton, and then the oxygenator pump was turned on. The larvicidal test consisted of two tests: the larvicidal test of the eggs containing embryos and the larvicidal test of the L2 larvae. Each test consisted of nine samples (positive control, negative control, and seven different AAE concentrations) containing 100 embryonic eggs and L2 larvae, respectively. For the first test, the eggs were maintained at ambient temperature until they came to contain embryos. The suspension containing hatched eggs and larvae was used for the second test. Various AAE concentrations were then added to the eggs containing embryos and to the L2 larvae for $48 \mathrm{~h}$, and then the dead and the live larvae were counted. Both tests were repeated three times.

\section{SCANNING ELECTRON Microscopy (SEM)}

Following the in vitro testing of the eggs and L2 larvae in various AAE concentrations, the specimens with the lowest AAE concentration (10\%) and the highest concentration (25\%), and the positive and negative controls, were fixed and examined via SEM. The fixation method consisted of rinsing in cacodylate buffer for $2 \mathrm{~h}$, pre-fixation in $2.5 \%$ glutaraldehyde for $48 \mathrm{~h}$, and fixation in $2 \%$ tannin acid. The specimens were washed four times with cacodylate buffer and distilled water. Finally, the specimens were dehydrated 
in a series of ascending alcohols, followed by drying in tertiary butanol. The dried specimens were coated with copper (JEOL JEC-3000FC/Auto Fine Coater) for 15 min.

\section{STATISTICAL ANALYSIS}

The data regarding the ovicidal and larvicidal activities of various $\mathrm{AAE}$ concentrations were analyzed using analysis of variance. If there were significant differences, the analysis was continued using Tukey's test and Statistical Package for the Social Sciences (SPSS) 7.0 for MS Windows. The SEM results were descriptively analyzed.

\section{RESULTS AND DISCUSSION}

The ovicidal and larvicidal activities of AAE are summarized in Table 1. All the AAE concentrations showed ovicidal activity, but $10 \%$ AAE did not show any larvicidal activity. The 25\% AAE concentration exhibited the most intense ovicidal and larvicidal activities, significantly differing $(p<0.05)$ from those of the negative control, while the ovicidal and larvicidal activities of $10 \%$ AAE were the least intense in all the parameters. The most intense ovicidal and larvicidal activities were found in $25 \% \mathrm{AAE}$, greater than the ovicidal and larvicidal activities of the positive control (5\% pyrantel pamoate).

Table 1: Impact of the ovicidal and larvicidal activities of Areca catechu crude aqueous extract (AAE) on A. galli.

\begin{tabular}{|c|c|c|c|}
\hline $\begin{array}{l}\text { Treat- } \\
\text { ments (\%) }\end{array}$ & $\begin{array}{l}\text { Ovicidal } \\
\text { activity }\end{array}$ & $\begin{array}{l}\text { Larvicidal activity } \\
\text { of eggs containing } \\
\text { embryos }\end{array}$ & ) \\
\hline AAE 10 & $3.20 \pm 1.84^{\mathrm{a}}$ & $0.73 \pm 0.75^{a}$ & $0.00 \pm 0.00^{\mathrm{a}}$ \\
\hline AAE 12.5 & $16 \pm 6.04^{b}$ & $9.83 \pm 6.04^{b}$ & $20.00 \pm 20.00^{a}$ \\
\hline AAE 15 & $49.26 \pm 4.10^{c}$ & $44.13 \pm 4.84^{c}$ & $20.00 \pm 20.00^{a}$ \\
\hline AAE 17.5 & $80.73 \pm 1.29^{d}$ & $75.53 \pm 0.83^{d}$ & $60.00 \pm 20.00^{b}$ \\
\hline AAE 20 & $81.76 \pm 0.47^{d}$ & $82.53 \pm 0.67^{e}$ & $80.00 \pm 20.00^{b}$ \\
\hline AAE 22.5 & $91.90 \pm 0.36^{\mathrm{e}}$ & $85.50 \pm 2.69^{e}$ & $80.00 \pm 20.00^{b}$ \\
\hline AAE 25 & $97.16 \pm 0.25^{f}$ & $93.70 \pm 1.40^{f}$ & $100.00 \pm 5.67^{c}$ \\
\hline $\begin{array}{l}\text { Pyrantel } \\
\text { pamoate }\end{array}$ & $96.56 \pm 0.71^{\mathrm{f}}$ & $93.43 \pm 0.75^{f}$ & $.00 \pm 0.00^{c}$ \\
\hline $\begin{array}{l}\text { Distilled } \\
\text { water }\end{array}$ & $0 \pm 0.00^{\mathrm{a}}$ & $\pm 0.00^{\mathrm{a}}$ & $\pm 0.00^{a}$ \\
\hline \multicolumn{4}{|c|}{$\begin{array}{l}\text { a, b, c, d, e, f the different superscripts in the same column were } \\
\text { indicative of significant differences }(\mathrm{P}<0.05) \text {. The same } \\
\text { superscripts in the same column were indicative of the absence of } \\
\text { significant difference. AAE = Areca catechu crude aqueous extract. } \\
\text { A. galli = Ascaridia galli. }\end{array}$} \\
\hline
\end{tabular}

The death of the eggs and larvae of $A$. galli in this study was considered the result of the presence of secondary compounds, especially tannin and saponin in AAE. In the study by Eguale et al. (2011), plants containing alkaloid, flavonoid, saponin, steroid, anthraquinone, and tannin were able to hamper embryonization and the egg-hatching process and cause the death of larvae through hot-water and methanol extraction. Wetwitayaklung et al. (2006) reported that the percentage of tannins from the water extract of 8 -month-old $A$. catechu seeds in their study was $31.56 \%$, and the percentage of total phenols was $38.59 \mathrm{~g} / 100 \mathrm{~g}$.

The larvicidal activity of AAE resulted from its tannin content. In the study by Sharma et al. (2010), tannin was able to hamper the formation of energy in worms by impeding the oxidative phosphorylation process. The antiparasitic activity of the condensed tannin was related to its capacity to bind to the cellular-membrane proteins. The binding of the proteins decreased the number of proteins available for the larvae, which subsequently resulted in the starvation and death of the larvae (Athanasiadou et al., 2001).

Tanniferous plants such as Meliaceae have been studied by Hammond et al. (1997) and have been proven to have the ability to hamper larvae growth (69\%). At high concentrations, the extracts of tanniferous plants were able to significantly hamper the development of the L1 and L2 larvae.

The eggs, larvae, and adult worms of $A$. galli that were alive and that were dead after the treatment are illustrated in Figure 1. The eggs and larvae that were alive after the treatment absorbed Lugol's solution (became red in color) while the eggs and larvae that died from the treatment did not absorb the said solution (remained transparent). The dead adult worms looked pale and stiff.

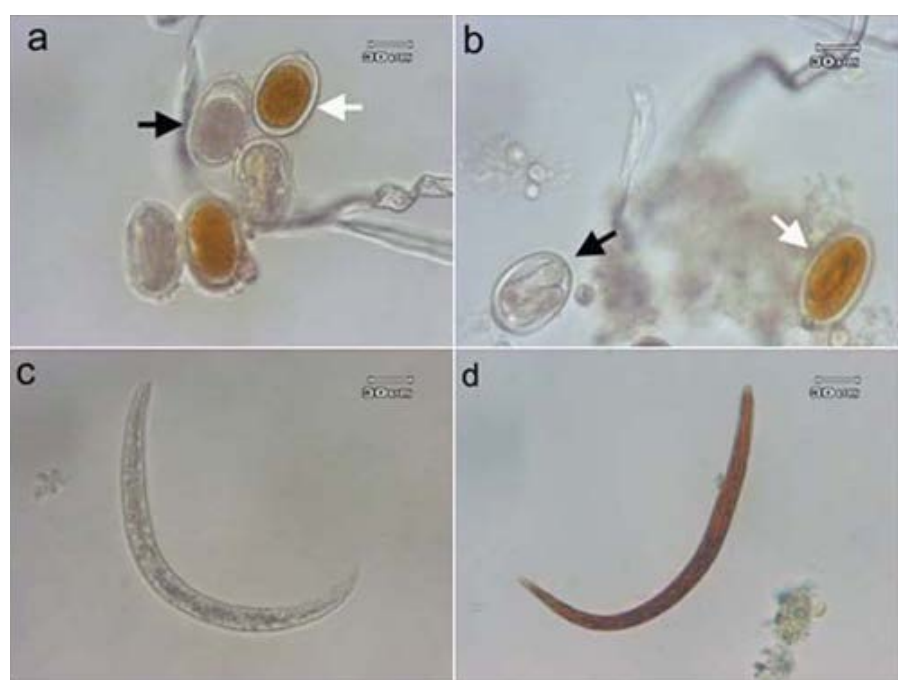

Figure 1: Ovicidal and larvicidal activities of Areca catechu crude aqueous extract (AAE).

(a) The dead eggs (black arrow) and the surviving eggs (white arrow), (b) The dead eggs with hampered embryo formation (black arrow) and the eggs containing the surviving embryo (white arrow), (c) The dead larvae, (d) The surviving larvae. 
The ultrastructures of the eggs and the L2 larvae at each AAE concentration can be seen in Figures 2 and 3, respectively. Damage occurred to the eggs' walls and also within the eggs. The walls became rough, shrunk, and ruptured, and the contents of the egg got dissolved. The larvae's SEM results showed no change in the negative control or at 10\% AAE; however, at 25\% AAE and in the positive control, the transverse grooves that normally cover the cuticles of $A$. galli were no longer observed.

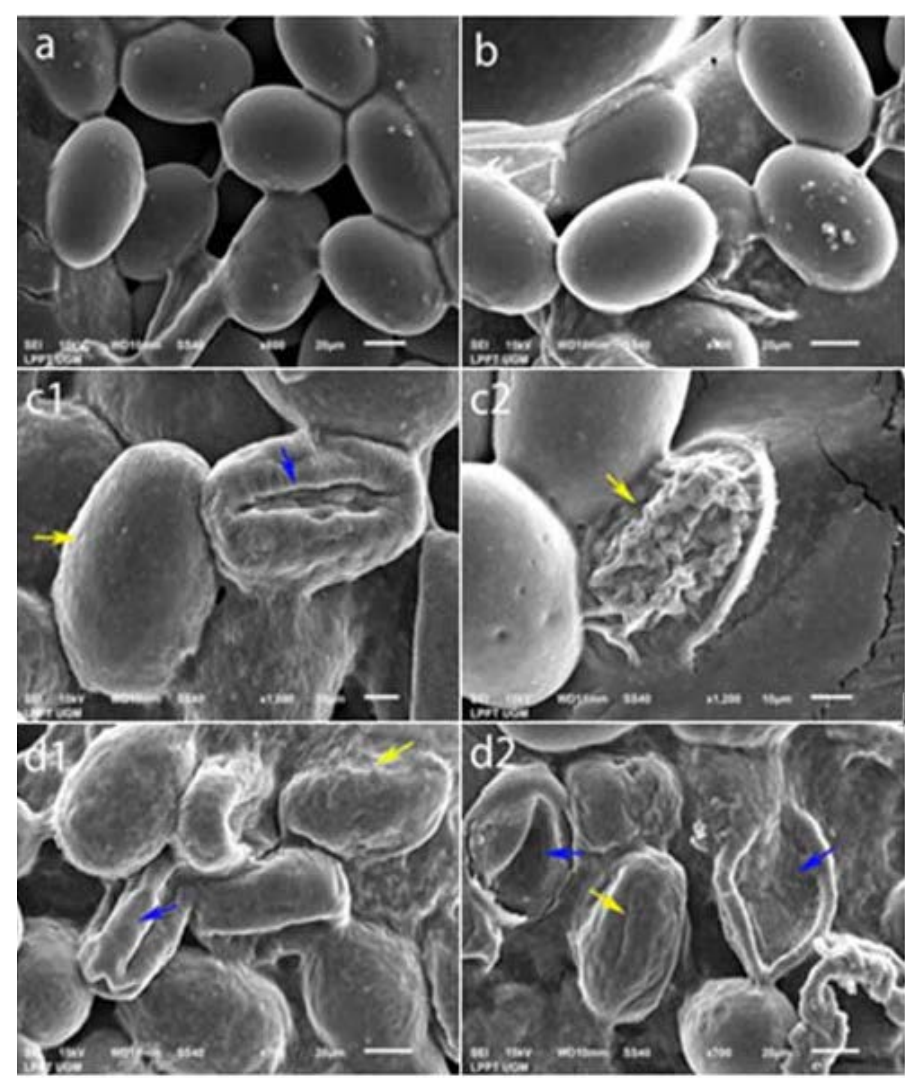

Figure 2: Egg ultrastructure ovicidal test results.

(a) Negative control. (b) 10\% concentration: normal. (c1) $25 \%$ concentration: dotted egg wall surface (yellow arrow), shrinking egg wall (blue arrow). (c2) 25\% concentration: ruptured egg wall (yellow arrow). (d1) Positive control: rough egg wall surface (yellow arrow), shrinking egg wall (blue arrow). (d2) Positive control: contracting egg wall (yellow arrows), ruptured egg wall losing its contents (blue arrow).

According to Adamczyk et al. (2010), even small amounts of tannin will bond with chitin and will form deposits. Christenson et al. (1942) reported that the eggs of $A$. galli have three layers: The vitelline membrane or internal lipoid, the true chorion, and the cuticle shell (chitinoid), which are relatively thick and contain thin proteinases; therefore, it can be deduced that tannin will damage the egg's shell by forming tannin or tannin-protein complexes. In the study by Kamel et al. (2017), the damages to the tegument in both adult and young Schistosoma mansoni worms included erosion and the peeling of the tegument itself.
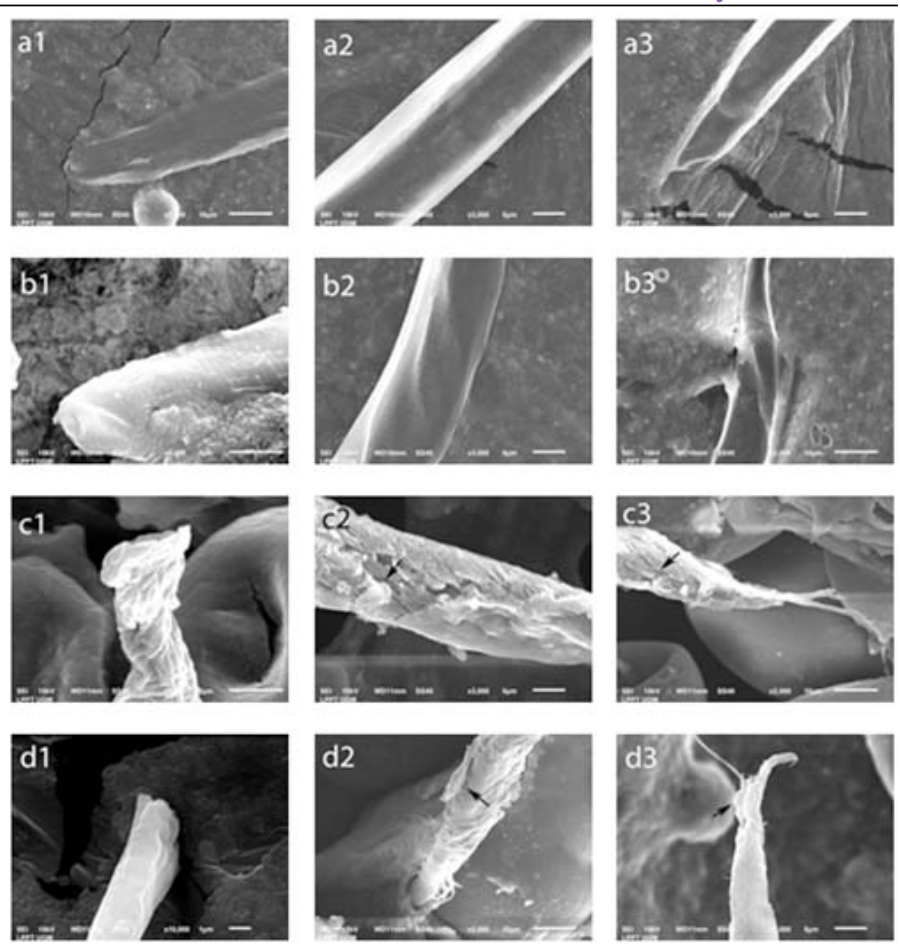

Figure 3: Larvae ultrastructure larvicidal test results.

(a) Negative control and (b) 10\% concentration: normal. (c1) $25 \%$ concentration: the teguments of the anterior larvae shrink. (c2, c3) 25\% concentration: the cuticle rupture/peel (arrow). (d1) Positive control: the anterior parts of the larvae begin to peel off. (d2, d3) Positive control: the cuticle rupture/peel (arrow).

Tannin (in condensed form) contains proline-rich protein, which is known to form the structure of the nematode cuticle (Hoste et al., 2006). Tannin can be proposed as a nematode control mechanism, thus blocking the parasite's physiological processes. Also, tannin can modify the host immune responses to eliminate infective larvae and adult worms (Zhong et al., 2014). Finally, tannin can interact with multiple lipid layers by binding to the cholesterol that may be found in the cuticles of several nematodes. The primary interaction of condensed tannin may take place along the cuticle lines through the insertion of condensed tannin into the lipid layer (glycosylation). The secondary interaction, which is with the collagen proline-rich layer, will result in the further interference of the hypodermal cells (Ropiak et al., 2016).

Saponin was reported to have a nematicidal content that could interact with the cellular membranes and cause changes in cellular wall permeability (Ademola and Eloff, 2010). Saponin and tannin were also reported to interact with the collagen proteins of the nematode cuticle, and the interaction might have a nematotoxic effect (Argentieri et al., 2008).

As with tannin and saponin, anthraquinones and flavonoids may also be related to anthelmintic activity. 
Several anthraquinones were successfully tested against Brugia malayi and Schistosoma mansoni (Dhanajeyan et al., 2005). Novel anthraquiones (1a-1k) had intense larvicidal activities against Culex quinquefasciatus compared to the standard permethrin (Selvaraj et al., 2021). According to Romero et al. (2020), glycosylated flavonoids and methoxyphenol are compounds with anthelmintic effects. The flavonoid fraction of $A$. sisalana inhibited the egg hatching of gastrointestinal nematodes by inhibiting the activity of enzymes and/or the metabolic processes of parasites (Botura et al., 2013).

\section{CONCLUSIONS AND RECOMMENDATIONS}

On the basis of the results of this study, it can be concluded that AAE has ovicidal and larvicidal activities against the parasitic worm $A$. galli. The SEM results showed shrinkages, ruptures, and general damages on the surfaces of the egg walls. The anterior teguments of the L2 larvae shrank and the cuticles got ruptured at 25\% AAE. The most intense ovicidal and larvicidal activities of AAE took place at the $25 \%$ concentration.

\section{NOVELTY STATEMENT}

This research is the first to study the ultrastructure of eggs and larvae of $A$. galli in native chickens treated using betel nut extract. Both eggs and larvae were treated were damaged which is evidence that betel nut has ovicidal and larvicidal activity against $A$. galli.

\section{AUTHOR'S CONTRIBUTION}

KK supervised the present study. WN and JP designed and coordinated the study. WM, BS, WN, JP, PS and KK performed the experiment. PS analyzed the data and wrote the manuscript. The final manuscript has been read and developed in consultation with all authors.

\section{CONFLICT OF INTEREST}

The authors have declared no conflict of interest.

\section{REFERENCES}

-Abbas G, Rehman MZU, Ali A, Fiaz A, Mahfooz A (2016). Effect of use of different anthelmintics (piperazine citrate and ivermectine) on blood profile of infested poultry (commercial and rural layers). Adv. Zoo. Bot., 4(1): 1-5. https://doi.org/10.13189/azb.2016.040101

-Adamczyk B, Adamczyk S, Smolander A, Kitunen V (2010). Tannic acid and Norway spruce condensed tannins can precipitate various organic nitrogen compounds. Soil Biol. Biochem., 43(3): 629-637. https://doi. org/10.1016/j.soilbio.2010.11.034
- Adate PS, Parmesawaran S, Chauhan Y (2012). In vitro anthelmintic activity of stem extracts of Piper betle Linn against pheritima posthuma. Phcog. J., 4(29): 61-65. https:// doi.org/10.5530/pj.2012.29.10

-Ademola OI, Eloff JN (2010). In vitro anthelmintic activity of Combretun molle against Haemonchus contortus ova and larvae. Vet.Parasitol.,169(1-2):198-203. https://doi.org/10.1016/j. vetpar.2009.12.036

-Amudhan MS, Begum VH, Hebbar KB (2012). A review on phytochemical and pharmacological potential of Areca catechu L. seed. Int. J. Pharm. Sci. Res., 3(11): 4151-4157.

-Argentieri PM, D’Addabbe T, Tava A, Agostinelli A, Jurzysta M, Avato P (2008). Evaluation of nematicidal properties of saponins from Medicago sativa spp. Eur. J. Plant Pathol., 120(2): 189-197. https://doi.org/10.1007/s10658-0079207-8

-Athanasiadou S, Kyriazakis I, Jackson F, Coop RL (2001). Direct anthelmintic effects of condensed tannins towards different gastrointestinal nematodes of sheep: In vitro and in vivo studies. Vet. Parasitol., 99(3): 205-219. https://doi. org/10.1016/S0304-4017(01)00467-8

- Baby AA, Raphael RK (2014). Potential antimicrobial, anthelmintic and antioxidant properties of Areca catechu L. root. Int. J. Pharm. Pharm. Sci., 6(6): 486 - 489.

-Balqis U, Hambal M, Rinidar, Athaillah F, Ismail, Azhar, Vanda H, Darmawi (2017). Cuticular surface damage of Ascaridia galli adult worms treated with Veitchia merrillii betel nuts extract in vitro. Vet. World, 10(7): 732 - 737. https://doi. org/10.14202/vetworld.2017.732-737

- Botura MB, dos Santos JD, da Silva GD, de Lima HG, de Oliveira JV, deAlmeida MAO, Batatinha MJM, Branco A (2013). In vitro ovicidal and larvicidal activity of Agave sisalana Perr. (sisal) on gastrointestinal nematodes of goats. Vet. Parasitol., 192: 211-217. https://doi.org/10.1016/j. vetpar.2012.10.012

- Cervantes-Rivera K, Villagomez-Cortes JA, Arroyo-Lara A, Landin-Grandvallet LA (2016). A diagnostic survey of gastroenteric helminths in backyard poultry of a rural village in Mexican tropics. ARPN J. Agric. Biol. Sci., 11(12): 463469.

- Christenson RO, Earle HH Jr, Butler RL Jr, Crell HH (1942). Studies on the eggs of Ascaridia galli and Heterakis gallinae. Trans. Am. Microsc. Soc., 61(2): 191-205. https://doi. org/10.2307/3222847

- Coles GC, Bauer FHM, Borgsteede S, Greets S, Klei TR, Taylor MA, Waller PJ (1992). World Association for the Advancement of Veterinary Parasitology (W.A.A.V.P.) methods for the detection of anthelmintic resistance in nematodes of veterinary importance. Vet. Parasitol., 44(12): 35-44. https://doi.org/10.1016/0304-4017(92)90141-U

- Daryatmo J, Hartadi H, Orskov ER, Adiwimarta K, Nurcahyo W (2010). In vitro screening of various forages for anthelmintic activity on Haemonchus contortus eggs. Adv. Anim. Biosci., 1(1): 113. https://doi.org/10.1017/S2040470010002566

- Dhananjeyan MR, Milev YP, Kron MA, Nair MG (2005). Synthesis and activity of substituted anthraquinones against a human filarial parasite, Brugia malayi. J. Med. Chem., 48: 2822-2830. https://doi.org/10.1021/jm0492655

- Eguale T, Tadesse D, Giday M (2011). In vitro anthelmintic activity of crude extract of five medicinal plants against egg-hatching and larval development of Haemonchus contortus. J. Ethnopharmacol., 137(1): 108-113. https://doi. org/10.1016/j.jep.2011.04.063 
-Erwiyani AR, Gultom DSR, Oktianti D (2021). Total flavonoid content of pinang seed extract (Areca catech $u \mathrm{~L})$ using $\mathrm{AlCl}_{3}$ method. Ind. J. Pharm. Nat. Prod., 4(1): 1-7.

-Hammond JA, Fielding D, Bishop SC (1997). Prospects for plant anthelmintics in tropical veterinary medicine. Vet. Res. Commun., 21(3): 213-218. https://doi. org/10.1023/A:1005884429253

- Hoste H, Jackson F, Athanasiadou S, Thamsborg SM, Hoskin SO (2006). The effects of tannin-rich plants on parasitic nematodes in ruminants. Trends Parasitol., 22(6): 253-261. https://doi.org/10.1016/j.pt.2006.04.004

-Kamel ROA, El-Zahraa F, Bayaumy A (2017). Ultrastructural alterations in Schistosoma mansoni juvenile and adult male worms after in vitro incubation with primaquine. Memórias do Instituto Oswaldo Cruz, Rio de Janeiro. 112(4): 247-254. https://doi.org/10.1590/0074-02760160324

-Lalchhandama K, Roy B, Dutta BK (2009). Anthelminthic activity of Acacia oxyphylla stem bark against Ascaridia galli. Pharm. Biol., 47(7): 578-583. https://doi. org/10.1080/13880200902902463

- Maclnnis AJ, Marietta V (1970). Experiments and techniques in parasitology. San Francisco, CA, USA: Freeman.

-Mubarokah WW, Nurcahyo W, Prastowo J, Kurniasih K (2019). The population, protein profile and ultrastructure of Ascaridia galli in chicken treated using Areca catechu crude aqueous extract. J. Indonesian Trop. Anim. Agric., 44(4): 392-399. https://doi.org/10.14710/jitaa.44.4.392-399

- Prastowo J, Herawati O, Ariyadi B, Kurniasih (2017). Effects of Areca catechu seed and Anredera cordifolia leaf on Ascaridia galli infection in the domestic chicken (Gallus gallus domesticus). Int. J. Poult. Sci., 16: 494-499. https://doi. org/10.3923/ijps.2017.494.499

-Romero N, Areche C, Cubides-Cárdenas J, Escobar N, GarcíaBeltrán O, Simirgiotis MJ, Céspedes Á (2020). In vitro anthelmintic evaluation of Gliricidia sepium, Leucaena leucocephala, and Pithecellobium dulce: fingerprint analysis of extracts by UHPLC-orbitrap mass spectrometry. Mol., 25: 1-17. https://doi.org/10.3390/molecules25133002
-Ropiak HM, Desrues O, Williams AR, Ramsay A, MuellerHarvey I, Thamsborg SM (2016). Structure-activity relationship of condensed tannins and synergism with trans-cinnamaldehyde against Caenorbabditis elegans. J. Agric. Food Chem., 64(46): 1-40. https://doi.org/10.1021/ acs.jafc.6b03842

-Salam ST (2015). Ascariasis in backyard chicken, prevalence, pathology and control. Int. J. Recent Sci. Res., 6(4): 33613365.

-Selvaraj K, Ali D, Alarifi S, Chidambaram SK, Radhakrishnan S, Akbar I (2021). Larvicidal activity of novel anthraquinone analogues and their molecular docking studies. Saudi J. Biol. Sci., 28(1): 157-162. https://doi.org/10.1016/j. sjbs.2020.09.028

-Sharma US, Sharma UK, Singh A, Sutar N, Singh PJ (2010). In vitro anthelmintic activity of Murraya koenigii linn. leaves: Extracts. Int. J. Pharma. Biol. Sci., 1(3): 1-4.

- Silalahi M (2020). Benefits and toxicity of Areca catechu in human health. Bina Gen.: Jur. Kes. 11(2): 26-31.

- Teixeira M, Monteiro JP, Catenacci LS, Rodrigues MLA, Sato MCB (2012). Ascaridiasis in peafowl Pavo cristatus (Phasianidae) due to Ascaridia galli Schrank, 1788. J. Zoo Wildl. Med., 43(3): 585-587. https://doi. org/10.1638/2011-0122R2.1

-Wetwitayaklung P, Phaechamud T, Limmatvapirat C, Keokitichai S (2006). The study of antioxidant capacity in various parts of Areca catechu L. Naresuan Univ. J., 14(1): 1-14.

-Yusuf KH, Ajanusi OJ, Lawal AI, Saidu L, Jatau ID (2016). Effects of Ascaridia galli infection in two breeds of broilers. Int. J. Poult. Sci., 15(2): 72-75. https://doi.org/10.3923/ ijps.2016.72.75

-Zhong RZ, Sun HX, Liu HW, Zhou DW (2014). Effects of tannic acid on Haemonchus contortus larvae viability and immune responses of sheep white blood cells in vitro. Parasite Immunol., 36(2): 100-106. https://doi.org/10.1111/ pim.12092 